\title{
From a reader to a scientist: developing cirgi learning to empower scientific literacy and mastery of biology concept
}

\author{
Rizhal Hendi Ristanto ${ }^{*}$, Siti Zubaidah', Mohamad Amin'2, Fatchur Rohman' \\ ${ }^{1}$ Biology Education, Faculty of Mathematics and Natural Science, Universitas Negeri Jakarta \\ ${ }^{2}$ Biology Education, Faculty of Mathematics and Science, Universitas Negeri Malang
}

*Corresponding author: rizhalhendi@unj.ac.id

\section{A R T I C L E I N F O}

Article history:

Received 23 September 2018

Revised 3 November 2018

Accepted 6 November 2018

Keywords:

CIRC, CirGI, guided inquiry,

instructional kit.

\begin{abstract}
A B S T R A C T
There are many studies on biology learning for primary school prospective teachers have been conducted in order to improve learning quality. This research aimed to produce a learning design in form of integrated instructional kit of CIRC and guided inquiry (CirGI). The research method used was research and development adapted from $4 D$ development model of Thiagarajan consisted of define, design, develop, and disseminate stages. The research was limited up to the develop stage. The research result indicated that the product of CirGi instructional kit development in form of the syllabus, lesson plan, student worksheets, and evaluation instruments in form of scientific literacy and mastery of biology concept for primary school in Primary School Teacher Education in Pakuan University. The research result is expected to give a contribution to learning and to be further developed to achieve Biology learning objectives that could empower scientific literacy and the mastery of biology concept.
\end{abstract}

(C) 2018 Universitas Negeri Jakarta. This is an open access article under the CC-BY license (https://creativecommons.org/licenses/by/4.0)

\section{INTRODUCTION}

Lately, a research focus on primary school teacher competence receives a special attention. Several research results indicate that primary school teachers in Indonesia are still not as expected. The mastery of teachers with an educational background of D2 PGSD (two years diploma of primary school teacher education) (UPJJ Bandung, Bogor, Jakarta, Bali) on the ability in sciences and its application in the learning is still low (Budiastra, 2011). The understanding of primary school teachers in Bandung Regency on the nature of science in the learning process is very low (Susilawati, 2009). Primary school teachers in East Kalimantan have less competence in understanding science subjects 
compared to other subjects (Suparlan, 2008). The misconception level of primary school teachers of natural science subjects is more than $30 \%$ (Puja, 2011) and their creativity needs to be improved (Mujakir, 2015).

The indication of the low competence is also found in primary school prospective teachers. An observation result indicates that conceptual understanding and scientific literacy of college students is in the low category. According to Cavas, et al., (2013), primary school prospective teachers need to have scientific literacy when teaching natural science subject in the future. Teachers who have a high scientific literacy produce literate students. Literacy relates to one's reading comprehension ability (Ristanto, 2017). According to Rustono (2010), one of the success factors for student in learning is reading comprehension ability.

In college learning process, lecturers are expected to have skill in developing a learning design that could facilitate students of prospective teacher to achieve learning objectives. Learning should involve students directly in inquiry process or by studying various reading sources (Ristanto et al., 2017; 2018).

It is believed that inquiry activities could train students to describe objects and events, ask questions, build explanation, test the explanation of sophisticated scientific knowledge, and communicate their ideas to others. Students are capable of identifying assumptions, utilizing critical thinking and logic, and considering alternative explanations (Ristanto, 2010). It is expected that through inquiry activities, students could be more active in developing the mastery of biology concept by combining their knowledge with their reasoning and thinking skills.

Lee et al., (2009) states that guided inquiry learning could improve the ability of giving argument and help students to be skillful in problem solving. Questions in guided inquiry closely relates to thinking skill since it could train students in utilizing various viewpoints in express opinion. A deeper thinking process produces argument based on evidences in a complex problem solving. According to Butler (2011), guided inquiry learning has proven to actively involve student of nonscience department in their learning and in understanding the contents deeper. Students need to be trained to investigate early and once they get use to inquiry activities, their understanding of biology concept and scientific literacy as well as research skill will improve (Carlson, 2008; Gormally et al., 2009, Adolphus; et al., 2012). In addition, guided inquiry learning could improve students' scientific literacy ability (El Islami, 2013; Ngertini, et al., 2013).

Guided inquiry learning model aims to give a way to the students to build intellectual proficiency or thinking proficiency related to reflective thinking process through educator's guide (Ristanto, 2011). According to Kubicek (2005), inquiry based learning could improve students' understanding by involving them in the process of learning activities actively thus the achieved concept is better. The implementation of guided inquiry learning model in college allows students to actively involved in using physical process to find several concepts and material principles learned by themselves with a guide from the lecturer thus it could develop students' concept and moral (Ristanto, et al., 2017).

Based on the characteristics, inquiry learning model is a suitable learning model to be implemented in the course of Basic Concept of Primary School Biology. In biology learning process, an activity is needed that could change students so they could find a concept through direct creativities either through a reading source study activity or inquiry. Biology learning should not base only on the lecturer but also the active involvement of students to train reading comprehension ability (Djamahar, et al., 2018); therefore, the product produced is not only the mastery of biology concept but also the ability to apply it to their future students (Ristanto, et al., 2018). One of learning models that train students to improve their ability and reading comprehension is cooperative learning type of Cooperative Integrated Reading and Composition (CIRC) (Ristanto, 2009; Hardiyanto, et al., 2016; Masnaini, et al., 2018).

An important step in CIRC learning model is that students in a heterogeneous group are demanded to find the essence of an article or content and then present it (Djamahar, et al., 2018; Ristanto, et al., 2018).CIRC learning has proven to be more effective than conventional learning in improving student learning outcome (Gupta, 2014a; Durukan, 2010). The main focus of CIRC is 
emphasizing on reading comprehension and writing process (Ristanto, 2009; Durukan, 2010; Halimah, 2014; Zainuddin, 2015).

Both learning models have their own strengths and weaknesses. CIRC learning emphasizes on reading process in a heterogeneous group and ends with group presentation. The learning process is in line with Basic Concept of Primary School Biology course that requires students to read more and analyze a reading or article to develop knowledge through terms or vocabularies discovery and new concepts in biology learning. The weakness of CIRC learning model is that only active students who will have more understanding on the content learned. Guided inquiry model, on the other hand, emphasizes on a scientific inquiry process by students according to scientific method steps and requires all students to be active in the inquiry activities. Guided inquiry learning steps is equipped with group discussion and presentation of students work result; therefore, the integration of both models is expected to be able to train students in improving their scientific literacy ability and mastery of biology concept.

The development of learning model by integrating both CIRC learning model and guided inquiry is supported by Bilgin's (2009) research result stated that students with guided inquiry group with cooperative learning had better understanding on the mastery of concept learned and indicated more positive attitude. According to Muraya \& Kimamo (2011), cooperative learning is more effective and significant in improving students' biology learning achievement and it is suggested to the lecturers to apply cooperative learning in biology learning.

The research aimed to produce valid and with high appropriateness instructional kit in the learning of basic concept of biology for primary school in Pakuan University. Instructional kit produced was in form of syllabus, learning plan, learning worksheets with pattern of CIRC and guided inquiry (CirGI) integration. The development result is expected to give benefit for the development of biology learning design in various levels.

\section{METHOD}

The research used research and development method adapted from Thiagarajan, et al., (1974), which was 4D (Define, Design, Develop, Disseminate). Each stage is explained below.

\section{A. Define Stage}

The stage aims to determine and define learning requirements. The stage consists of the following main steps: (a) front-end analysis, (b) student analysis, (c) assignment analysis, and (e) objectives formulation.

\section{B. Design Stage}

The design stage aims to design learning activities and instructional kit needed thus it produces prototype I. CirGI instructional kit is developed according to learning objectives and situation based on integrated learning model of CIRC and guided inquiry and in line with applicable curriculum at Pakuan Univesity. The initial design of the instructional kit consisted of syllabus, lesson plans, student worksheets, and learning evaluation instruments in form of scientific literacy test and the mastery of biology concept test.

Scientific literacy test was developed by referring to PISA indicators. The questions were multiple choices containing only one correct answer. Biology concept understanding test in form of grids, questions, assessment rubric, and answer key was developed based on Bloom taxonomy. Assessment rubric developed aimed to facilitate the examination of answers for each test item answered by the students.

\section{Develop Stage}

Thiagarajan et al., (1974) divided the develop stage into two activities: expert appraisal and developmental testing. The result in this stage was an instructional kit in form of prototype II.

\section{Expert appraisal}

Experts, in this case, referred to educational experts with qualification of Doctor in Biology Education and senior lecturers of Basic Concept of Biology for Primary School course. The validated 
media consisted of syllabus, lesson plan, student worksheets, and learning evaluation instruments in form of scientific literacy and metacognitive instruments.

\section{Development Testing}

Development testing was done on the validated media to students who had taken the course of Basic Concept of Biology for Primary School. The testing result was used as a base to determine the empirical validity and reliability of the evaluation instruments. The testing in this stage consisted validation test (content validation, construct validation, and empirical validation) and reliability test for each scientific literacy and metacognitive instruments.

\section{Result and Discussion}

The research result is discussed for each of the following stage:

\section{Define Stage}

The define stage in the development of CirGi instructional kit is explained by the following stages:

\section{a. Front-end Analysis}

Front-end analysis was conducted through a survey to lecturers of Basic Concept of Biology for Primary School course as well as lecturers who had taught the course. There were 5 lecturers involved in the stage. The survey activity was conducted in October, 2014. The question components consisted of the renewal aspects and the readiness of the instructional kit consisted of syllabus, lesson plans, student worksheets, and evaluation instruments by the lecturers, learning model used especially CIRC learning model and guided inquiry as well as the integration of both models, the measurement of scientific literacy along with the instruments used, and students' mastery of biology concept along with its measurement. The survey result can be seen in Table 1.

Table 1. The analysis of front-end survey result.

\begin{tabular}{clrr}
\hline \multirow{2}{*}{ No } & \multicolumn{1}{c}{ Questions } & \multicolumn{2}{c}{ Response \% } \\
\cline { 3 - 4 } & \multicolumn{1}{c}{ Yes } & No \\
\hline 1. & Prepare the instructional kit (syllabus, lesson plan instruments, student & 100 & 0 \\
& worksheets, and evaluation instruments). & 20 & 80 \\
2. & Compile the renewed lecture syllabus at the beginning of each semester & 20 & 80 \\
3. & Compile a renewed lesson plan instruments at the beginning of each semester & 100 & 0 \\
4. & Apply the model/method in every lecture & 20 & 80 \\
5. & Apply CIRC learning model & 100 & 0 \\
6. & Apply guided inquiry learning model & 40 & 60 \\
7. & Apply cooperative learning principles & 20 & 80 \\
8. & Develop student worksheets for every lecture & 100 & 0 \\
9. & Measure students' mastery of biology concept & 0 & 100 \\
10. & Compile instruments and assessment rubric of concept mastery & 20 & 80 \\
11. & Measure the scientific literacy ability & 20 & 80 \\
12 & Compile instruments and assessment rubric of scientific literacy &
\end{tabular}

Based on Table 1 it can be seen that all lecturers who taught Basic Concept of Biology for Primary School course had prepared the instructional kit, such as, syllabus, lesson plans, student worksheets, and evaluation instruments. The lecturers also had applied various learning models or methods in each lecture, including guided inquiry learning model and measured students' mastery of biology concept through quizzes, midterm exam, and final exam. The measurement of the mastery of biology concept did not followed by the forming of instruments and assessment rubric.

Of the instructional kit compiled, only $20 \%$ of the lecturers renewed the syllabus, lesson plan, and student worksheets instruments at the beginning of each semester. $40 \%$ of the lecturers had applied cooperative learning principles. Only $20 \%$ of the lecturers applied CIRC learning model, compiled and measured students' scientific literacy evaluation media. 


\section{b. Student Analysis}

Student analysis was conducted through workshop and discussion with the lecturers of the course and it was conducted at the beginning and end of semester, which was September 2014 and February 2015. The result of student analysis found the following:

1. Biology learning activity was not optimal. It was indicated by lecturer domination in the learning activity and the used of one way learning process.

2. Based on data from the origin of the school, PGSD students were dominated by non-natural sciences program of senior high school. It was identified as a factor for the low mastery of biological concept.

3. Students experienced difficulties in biology learning especially in understanding Latin language in the course of Basic Concept of Biology for Primary School.

4. The observation result indicates that scientific literacy in the content aspect, process and attitude were low.

\section{c. Assignment Analysis}

Based on the front-end analysis and student analysis, efforts were needed to improve scientific literacy ability and the mastery of biology concept. The result of assignment analysis in this research was in form of competence standard and basic competence of Basic Concept of Biology for Primary School course.

\section{d. Concept Analysis}

The result of analysis obtained the main concepts based on competence standard and basic competence. The competency standard for Basic Concept of Biology for Primary School of FKIP (Faculty of Teacher Training and Education) Pakuan University referred for the study consisted of 8 subjects described in 26 main contents, subjects, competence standard, basic competence, and main contents of Basic Concept of Biology for Primary School of FKIP Pakuan University.

\section{e. The Formulation of Learning Objectives}

Based on the result of assignment analysis and concept analysis, learning objectives were produced. In the research, the formulation of learning objectives included the formulation of accomplishment indicators based on the competence standard and basic competence in the curriculum of Basic Concept of Biology for Primary School of FKIP Pakuan University.

\section{Design Stage}

This stage produced learning activities design and instructional kit needed. Instructional kit products consisted of syllabus, lesson plans, student worksheets, and evaluation instruments in form of scientific literacy ability test and the mastery of biology concept test. The Syllabus was developed by referring to the curriculum of Basic Concept of Biology for Primary School. The result of learning activities design and the instructional kit produced was called prototype (draft I). Learning plan and media developed and used during the research can be explained as follows.

\section{a. Syllabus}

Syllabus developed referred to the curriculum of Basic Concept of Biology for Primary School. The main components of the syllabus consisted of course description, competence standard, basic competence, course content, accomplishment indicators, assessment, time allocation, instructional kit, learning sources, and bill. The syllabus used standardized format of FKIP Pakuan University. However, the learning model part was adjusted to the research purpose, which was using CirGI.

\section{b. Lesson Plan Instrument}

Lesson plan compiled referred to the learning model used. The lesson plan components consisted of competence standard, basic competence, learning content, accomplishment indicators, learning model and methods, learning syntax, assessment, instructional kit, learning sources, and college bills. Lesson plans was developed by referring to the CirGI learning model syntax used in the experimental research, which was CIRC learning model syntax and guided inquiry as indicated in Table 4. 
Table 4. Learning model syntax of circ and guided inquiry integration (CirGI).

\begin{tabular}{|c|c|c|}
\hline \multirow{2}{*}{ CirGI Syntax } & \multicolumn{2}{|c|}{ Learning Activities } \\
\hline & Lecturer & Student \\
\hline $\begin{array}{l}\text { Stage } 1 . \\
\text { Form a heterogeneous group }\end{array}$ & $\begin{array}{l}\text { 1. Explain the learning model, } \\
\text { logistic, and the } \\
\text { implementation. } \\
\text { 2. Convey the lecture objectives } \\
\text { 3. Motivate students and link the } \\
\text { present content to the previous } \\
\text { one. } \\
\text { 4. Guide student to form a } \\
\text { heterogeneous group } \\
\text { consisted of } 4-5 \text { student } \\
\text { (CIRC). }\end{array}$ & $\begin{array}{l}\text { 1. Pay attention on and take note of } \\
\text { the lecture } \\
\text { 2. Students put themselves in their } \\
\text { own group (CIRC). }\end{array}$ \\
\hline $\begin{array}{l}\text { Stage } 2 . \\
\text { Read, discuss, and find the } \\
\text { main concepts of the article. }\end{array}$ & $\begin{array}{l}\text { 1. Guide students to prepare } \\
\text { articles/reading material with } \\
\text { topic according to the content } \\
\text { learned (CIRC). } \\
\text { 2. Give opportunity to students to } \\
\text { read, discuss, and understand } \\
\text { the article (CIRC). } \\
\text { 3. Guide students in finding } \\
\text { important facts, the main } \\
\text { concept of the article, and } \\
\text { rewrite them on the student } \\
\text { worksheet (CIRC). }\end{array}$ & $\begin{array}{l}\text { 1. Prepare articles/reading } \\
\text { materials according to the } \\
\text { content topic learned (CIRC). } \\
\text { 2. Students read, discuss, and } \\
\text { rewrite the important facts of the } \\
\text { main concept and article } \\
\text { responses on the student } \\
\text { worksheet (CIRC). }\end{array}$ \\
\hline $\begin{array}{l}\text { Stage } 3 . \\
\text { Formulate problems }\end{array}$ & $\begin{array}{l}\text { 1. Guide students to formulate } \\
\text { solvable problems (guided } \\
\text { inquiry). }\end{array}$ & $\begin{array}{l}\text { 1. Formulate problems and consult } \\
\text { the problem formulation to the } \\
\text { lecturer (guided inquiry). }\end{array}$ \\
\hline $\begin{array}{l}\text { Stage } 4 . \\
\text { Formulate hypothesis }\end{array}$ & $\begin{array}{l}\text { 1. Guide students to submit } \\
\text { hypothesis of the formulated } \\
\text { problems (guided inquiry). }\end{array}$ & $\begin{array}{l}\text { 1. Write the hypothesis (guided } \\
\text { inquiry). }\end{array}$ \\
\hline $\begin{array}{lll}\text { Stage } 5 . & & \\
\text { Conduct } & \text { group } \quad \text { inquiry } \\
\text { activities }\end{array} \quad$ & $\begin{array}{l}\text { 1. Guide students to collect } \\
\text { information according to } \\
\text { problem formulation (guided } \\
\text { inquiry). } \\
\text { 2. Guide students to obtain } \\
\text { explanation through inquiry } \\
\text { process and problem solving } \\
\text { from various sources (guided } \\
\text { inquiry). }\end{array}$ & $\begin{array}{l}\text { 1. Collect information suitable to } \\
\text { the problem topics discussed to } \\
\text { solve problems (guided inquiry). } \\
\text { 2. Consult the problem solving } \\
\text { information during group work } \\
\text { process. } \\
\text { 3. Write the inquiry result on the } \\
\text { student worksheet. }\end{array}$ \\
\hline $\begin{array}{l}\text { Stage } 6 . \\
\text { Develop and present the work }\end{array}$ & $\begin{array}{l}\text { 1. Help students to plan and } \\
\text { prepare student worksheet to } \\
\text { be presented or displayed } \\
\text { (CIRC). } \\
\text { 2. Help students to divide tasks } \\
\text { in the group } \\
\text { 3. Direct students to give an } \\
\text { opinion on other group } \\
\text { presentations (CIRC). } \\
\text { 4. Give opinion and suggestion } \\
\text { on responses put forward by } \\
\text { the students during group } \\
\text { presentation (CIRC). }\end{array}$ & $\begin{array}{l}\text { 1. Plan and prepare the work to be } \\
\text { presented and discussed based on } \\
\text { learning activity report student } \\
\text { worksheet. } \\
\text { 2. Present the work (CIRC). } \\
\text { 3. Give comment, opinion on the } \\
\text { work of other groups displayed } \\
\text { or presented (CIRC). }\end{array}$ \\
\hline
\end{tabular}


CirGI Syntax

Stage 7.

Analyze, evaluate the inquiry process and draw conclusions
Learning Activities

Lecturer

1. Help students to reflect or evaluate the result of enquiry they used (CIRC).

2. Help students to draw conclusion from the learning process.

3. Ask students to improve the inquiry result or problem solving presented (CIRC and guided inquiry).

4. Give reward to the best group (CIRC).

\section{c. Student Worksheet}

Student worksheet in this research is an activity sheet consisted of instruction for the steps of learning process of Basic Concept of Biology for Primary School. The development of student worksheets in the research aimed to help students to improve their scientific literation and mastery of biological concept. Student worksheets developed referred to the learning model used, which was by adapting from CIRC and guided inquiry.

\section{d. Learning Evaluation Instruments}

Learning evaluation instruments developed in the research consisted of scientific literacy ability test and the mastery of biology concept test. Grids, questions, assessment rubric, and answer keys of scientific literacy competence test developed by the researcher referred to the scientific literacy competence by PISA. The grid, questions, and assessment rubric of the mastery of biology concept developed by the researcher were in accordance with Boom's taxonomy level revised by Anderson \& Krathwohl (2001), namely: remember (C1), understand (C2), apply (C3), analyze (C4), evaluate (C5), and create (C6).

\section{Develop Stage}

In the stage, validation test was conducted on instructional kit plan from the result of draft I. Validation test activity was conducted through two steps: expert appraisal and development testing. The result of validation test is explained as follows.

\section{a. The Result of Expert Validation}

Validation process was conducted by experts in natural sciences learning and biology education except the counselor. The validation process was conducted by Dr. Nandang Hidayat, M.Pd from Pakuan University and Dr. Baskoro Adi Prayitno S.Pd., M.Pd from Sebelas Maret University. The experts involved in the stage called as validator. The validation process used feasibility assessment sheet of instructional kit consisted of syllabus and lesson plans, feasibility assessment sheet of scientific literacy instruments and the mastery of biology concept, and feasibility assessment sheet of student worksheets. The experts gave correction on the correctness of concept, the accuracy of instructional, and the suitability for indicators in the dependent variable instruments developed. Data presentation of the validation results for each instrument is explained as follows.

\section{1) Syllabus}

The summary result of descriptive data analysis through data syllabus feasibility assessment obtained from validator one and validator two on the products developed can be seen in Table 5 .

Table 5 Summary of Syllabus Validation Analysis Result.

\begin{tabular}{llccc}
\hline No & Validator & Feasibility Percentage & Mean & Conclusion \\
\hline 1. & Validator I & $78,57 \%$ & \multirow{2}{*}{$81,25 \%$} & \multirow{2}{*}{ Very feasible } \\
2. & Validator II & $83,93 \%$ & \\
\hline
\end{tabular}

Based on Table 5 it can be concluded that the development of CirGI syllabus was in the category of feasible and can be implemented in Biology learning. 


\section{2) Lesson Plan Instrument}

The explanation of summary of descriptive data analysis result of feasibility assessment for lesson plans development obtained from the validators can be seen in Table 6 .

Table 6. Summary of validation analysis result of lesson plans.

\begin{tabular}{clccl}
\hline No & Validator & Feasibility Percentage & Mean & Conclusion \\
\hline 1. & Validator I & $80,00 \%$ & \multirow{2}{*}{$83,13 \%$} & \multirow{2}{*}{ Very feasible } \\
2. & Validator II & $86,25 \%$ & & \\
\hline
\end{tabular}

Based on Table 6 it can be concluded that CirGI-learning model lesson plans had a very feasible category and it could be well applied in biology learning.

\section{3) Student Worksheet}

The summary of descriptive data analysis result of student worksheets feasibility assessment by the validators can be seen in Table 7 .

Table 7 Summary of validation analysis result of student worksheets.

\begin{tabular}{clccc}
\hline No & Validator & Feasibility Percentage & Mean & Conclusion \\
\hline 1. & Validator I & $83,33 \%$ & \multirow{2}{*}{$85,42 \%$} & \multirow{2}{*}{ Very feasible } \\
2. & Validator II & $87,50 \%$ & \\
\hline
\end{tabular}

Based on Table 7 on the summary of validation analysis result of student worksheets, it can be seen that the validation result by the validators found that the development was in the very feasible category.

\section{4) Learning Evaluation Instrument}

Learning evaluation instrument validated in the research was an evaluation tool of scientific literacy and the mastery of biology concept. The result of descriptive data analysis of feasibility assessment for evaluation tool development of scientific literacy obtained from the validator assessment can be seen in Table 8 .

Table 8. Summary of validation analysis result of scientific literacy evaluation.

\begin{tabular}{clccc}
\hline No & Validator & Feasibility Percentage & Mean & Conclusion \\
\hline 1. & Validator I & $81,25 \%$ & $80,21 \%$ & \multirow{2}{*}{ Very Feasible } \\
2. & Validator II & $79,17 \%$ & 80 & \\
\hline
\end{tabular}

Based on Table 8 it can be seen that the validation result of scientific literacy ability evaluation tool had a very feasible category. Whereas, the descriptive data analysis result of feasibility assessment for the mastery of biology concept evaluation tool obtained from the validators assessment can be seen in Table 9.

Table 9. Summary of validation analysis result of the mastery of biology concept.

\begin{tabular}{clccc}
\hline No & Validator & Feasibility Percentage & Mean & Conclusion \\
\hline 1. & Validator I & $81,25 \%$ & \multirow{2}{*}{$81,25 \%$} & Very Feasible \\
2. & Validator II & $81,25 \%$ & \\
\hline
\end{tabular}

Based on Table 9 on the summary of validation analysis result of the mastery of biology concept, it can be concluded that the development of the mastery of biology concept evaluation tool had a very feasible category.

\section{b. Development Testing Result}

Testing on the media developed was conducted through small group testing. The tested instructional kit were student worksheets developed and learning evaluation instruments consisted of test questions on scientific literacy ability and the mastery of biology concept. The testing on student worksheets media consisted of legibility questionnaire and questionnaire of responses on student 
worksheets by students. The testing aimed to test the scientific literacy ability and the mastery of concept through empirical validity test and reliability test.

2. The analysis result of legibility questionnaire and students response on student worksheets questionnaire.

Legibility questionnaire and response on student worksheets questionnaire developed involved 20 students of Semester V of PGSD who had taken Basic Concept of Biology for Primary School Course. The summary of questionnaires analysis result can be seen in Table 10 .

Table 10 Summary of Analysis Result on legibility questionnaire and response to student worksheets questionnaire.

\begin{tabular}{cccc}
\hline No & Type of Questionnaire & Mean & Criteria \\
\hline 1 & Legibility questionnaire student worksheets & $93,28 \%$ & Very feasible \\
2 & Response on student worksheets questionnaire & $91,13 \%$ & Very feasible \\
\hline
\end{tabular}

Based on Table 10, it can be seen that the percentage of an analysis result of CirGI student worksheets legibility questionnaire was 93.28 with very feasible criteria. The analysis result of student response to CirGI student worksheets questionnaire was $91.13 \%$ with very feasible criteria.

\section{c. The Analysis Result of Empirical Validity Test and Reliability Test}

Empirical validity test and reliability test of scientific literacy ability test and the mastery of biology concept test were conducted to 36 respondents of PGSD students of Pakuan University. The respondents were active college students who had taken Basic Concept of Biology for Primary School Course. The requirement on the amount of correlation coefficient to be stated as valid was when the coefficient value is equal to or larger than 0.329 (the smallest is 0.329 ).

Based on the result of correlation product moment analysis, it can be seen that every item of question test on scientific literacy ability or on the mastery of biology concept had correlation value of more than 0.329 . It can be concluded that the result of empirical validity test in all question items in the research was stated as valid.

The result of reliability test, in overall, on the question items in scientific literacy ability test was 0.95 and the mastery of biology concept was 0.77 . Based on the calculation result, it can be concluded that all items of the learning evaluation instruments, either scientific literacy ability or the mastery of biology concept, had a strong or high reliability value.

\section{CONCLUSION}

Based on the research result, CirGI learning design in form of syllabus, course unit composition, student worksheets and Biology learning evaluation instruments in form of scientific literacy test and the mastery of biology concept test were stated as very feasible to be applied in the learning. It is expected that CirGI learning design could be further developed for the achievement of biology learning objectives that could empower scientific literacy and the mastery of biology concept.

\section{REFERENCES}

Adolphus., Telima., \& Rokoyu, A.A. (2012). Improving scientific literacy among secondary school students through integration of information and communication technology. ARPN Journal of Science and Technology, 2(5), 44-448.

Bilgin, I. (2009). The effects of guided inquiry instruction incorporating a cooperative learning approach on university students' achievement of acid and bases concepts and attitude toward guided inquiry instruction. Scientific Research and Essay, 4 (10), 1038-1046. 
Budiastra, A. A. K. (2011). Sejauhmana guru telah menguasai konsep keterampilan proses dan sejauhmana keterampilan proses tersebut dilaksanakan dalam pembelajaran ipa di sd. Laporan Penelitian, FKIP Universitas Terbuka.

Butler, A. E. (2011). Effectiveness of guided inquiry on students' comprehension of chemistry concepts in a non-science majors' course. (Unpublished Doctoral Thesis), University of Akron.

Carlson, J. L. (2008). Effect of theme-based, guided inquiry instruction on science literacy in ecology. (Unpublished Masters Thesis), Michigan Technological University, Michigan.

Cavas, P. H., Pınar, H., Ozdem, Y., Cavas, B., Cakiroglu, J., \& Ertepina, H. (2013). Turkish preservice elementary science teachers' scientific literacy level and attitudes toward science. Science Education International, 24(4), 383-401.

Djamahar, R., Ristanto, R. H., Sartono, N., Ichsan, I. J., \& Muhlisin, A. (2018). CIRSA: Designing Instructional Kits to Empower 21st Century Skill. Educational Process: International Journal, 7(3), 200-208. DOI: 10.22521/edupij.2018.73.4.

Durukan, E. (2011). Effects of cooperative integrated reading and composition (CIRC) technique on reading-writing skills. Educational Research and Reviews, 6(1), 102-109.

El Islami, R. A. Z. (2013). Menghasilkan guru yang profesional dan religius, bermoral, memiliki kompetensi sesuai dengan tuntutan masyarakat serta dapat melakukan pembinaan pengembangan sekolah dasar, meningkatkan kualitas guru sekolah dasar. (Tesis tidak diterbitkan), Universitas Pendidikan Indonesia, Bandung.

Gormally, C., Brickman, P, Hallar., B, \& Armstrong, N. (2009). Effects of inquiry-based learning on students' science literacy skills and confidence. International Journal for the Scholarship of Teaching and Learning, 3(2):364-377.

Halimah, A. (2014). Metode cooperative integrated reading and composition (circ) dalam pembelajaran membaca dan menulis di sd/mi. Auladuna: Jurnal Ilmu Pendidikan Dasar, 1(1), 27-35.

Hardiyanto, A., Sutarsyah, C., \& Suparman, U. (2016). Modified cooperative integrated reading and composition to promote students reading comprehension achievement. Unila Journal of English Teaching, 5(1), 1-14.

Puja, P. (2011). Miskonsepsi ipa pada guru sd. Jurnal Materi dan Pembelajaran Fisika,1(1), 22-24.

Kubicek, P.J. (2005). Inquiry-based learning, the nature of science, and computer technology: New possibilities in science education. Canadian Journal of Learning and Technology, 31(1), 1-5.

Masnaini, Copriady, j., Osman, K. (2018). Cooperative integrated reading and composition (CIRC) with mind mapping strategy and its effects on chemistry achievement and motivation. AsiaPacific Forum on Science Learning and Teaching, 19(1), 1-18.

Mujakir. (2015). Kreativitas guru ipa dalam pembelajaran ipa di sekolah dasar. Lantanida Jurnal, $3(1), 82-92$.

Muraya, D. N \& Kimamo, G. (2011). Effects of cooperative learning approach on biology mean achievement scores of secondary school students' in machakos district, kenya. Educational Research and Reviews, 6(12), 726-745.

Ngertini, N. N., Sadia, I.W., \& Yudana, I.M. (2013). Pengaruh implementasi model pembelajaran inkuiri terbimbing terhadap kemampuan pemahaman konsep dan literasi sains siswa kelas $\mathrm{x}$ sma pgri 1 amlapura. e-Journal Program Pascasarjana Universitas Pendidikan Ganesha, 4(10), 1-11. 
Lee, W. J., Puspitasari, K. A., Kim, H. Y., \& Jeong, A. (2009). The effects of guided inquiry questions on students' critical thinking skills and satisfaction in online argumentation. Florida: Florida State University.

Ristanto, R. H. (2009). Implementasi model pembelajaran kooperatif tipe circ cooperative integrated reading and composition) untuk meningkatkan hasil belajar biologi kelas xi ipa $i$ "topik gangguan sistem transportasi pada manusia "sma negeri 1 sambungmacan, sragen tahun ajaran 2008/2009. (Unpublish Thesis). Universitas Muhammadiyah Surakarta, Surakarta.

Ristanto, R. H. (2010). Pembelajaran berbasis inkuiri terbimbing dengan multimedia dan lingkungan rill ditinjau dari motivasi berprestasi dan kemampuan awal (Unpublished Masters Thesis), Universitas Sebelas Maret, Surakarta.

Ristanto, R. H. (2011). Pembelajaran biologi berbasis inkuiri terbimbing dengan multimedia dan lingkungan rill terhadap prestasi belajar. Jurnal Educatio, 6(1), 53-68.

Ristanto, R. H. (2017). Pengembangan perangkat pembelajaran integrasi cooperative integrated reading and composition (circ) dan inkuiri terbimbing serta pengaruhnya terhadap literasi sains dan penguasaan konsep biologi mahasiswa pgsd universitas pakuan, (Unpublished Doctoral Thesis), Universitas Negeri Malang, Malang.

Ristanto, R. H., Zubaidah, S., Amin, M., \& Rohman, F. (2017). Scientific literacy of students learned through guided inquiry. International Journal of Research and Review, 4(5), 23-30.

Ristanto, R. H., Zubaidah, S., Amin, M., \& Rohman, F. (2018). The potential of cooperative integrated reading and composition in. biology learning at higher education. International Journal of Educational Research Review, 3(1), 50-56.

Rustono. (2010). Pengaruh metode pembelajaran membaca dan tingkat keceerdasan terhadap kemampuan pemahaman bacaan. Jurnal Saung Guru: 1(2), 12-27.

Suparlan.(2008). Menjadi guru efektif. Yogyakarta: Hikayat.

Susilawati, S. (2009). Analisis Kemunculan Aspek-aspek Hakikat Sains dalam Praktik Pembelajaran Sains di Sekolah Dasar Serta Dampaknya terhadap Pemahaman Konsep dan Keterampilan Proses Sains Peserta Didik: Studi Kasus Naturalistik terhadap Pembelajaran Sains di SD Kelas IV Gugus VI Kecamatan Baleendah. (Unpublished Masters Thesis), Universitas Pendidikan Indonesia, Bandung.

Thiaragajan, S., Semmel, D.,S \& Semmel, M.L. (1974). Instructional development for training teachers of exceptional children. Minnsota: Indiana University

Zainuddin. (2015). The effect of cooperative integrated reading and composition technique on students' reading descriptive text achievement. English Language Teaching, 8(5), 11-21. 